\title{
SCALING ONLINE EDUCATION: INCREASING ACCESS TO HIGHER EDUCATION
}

\author{
Jacqueline F. Moloney \\ UMass Lowell and UMass Online
}

Burks Oakley II

University of Illinois and University of Illinois Online

\begin{abstract}
This paper reviews online enrollment trends in higher education, describes the characteristics of online programs that have scaled successfully to meet increasing demand, identifies challenges impacting the continued growth of online enrollments in this sector, and outlines the opportunities for increasing access to higher education through scaling of online initiatives.
\end{abstract}

\section{KEYWORDS}

Online Learning, Access to Higher Education, Online Enrollment Growth

\section{INTRODUCTION}

Over the past decade, online courses and entire online degree programs have been made available, serving millions of students in higher education. These online courses largely have been designed and taught using the theoretical concepts and practical strategies of Asynchronous Learning Networks (ALN) [1]. During 2003-04, approximately two million learners were engaged in higher education via ALN, and online enrollments are expected to grow at a $20 \%$ annual rate during the next few years [2]. The Sloan Consortium (Sloan-C) has worked to help institutions improve the quality of their online offerings [3], and research has shown that ALN is a viable alternative to classroom-based learning [4].

Enrollment in ALN courses and programs has grown for a number of reasons, all of which are linked to the Sloan-C quality pillars $[1,5]$. First and foremost, online courses provide new access to higher education for individuals who are place-bound and/or time-restricted-what has been termed "anytime, anyplace" learning. Online courses also are cost effective, and promote learning that can be as effective as in the classroom [1]. Yet despite the successes of ALN, a number of obstacles still block the dream of "anytime, anyplace" learning for any motivated individual — the full breadth of academic disciplines is not available online, and institutions have not been able to scale their ALN programs to meet the demand. The purpose of this paper is to identify a broad range of approaches for institutions of higher education in the USA that will allow continued growth of enrollments to meet the (still unmet) demand for access to quality online learning opportunities. There are several underlying questions that will be addressed in this article:

- Are there common factors related to successful online initiatives that have achieved significant scale?

- What obstacles need to be overcome for online enrollments to continue to increase to meet the needs of potential learners during the next decade?

- Why have some institutions embraced online learning, while others have yet to do anything in this area? 


\section{THE GROWTH OF ONLINE LEARNING}

Online learning has experienced tremendous growth in the past decade. It is instructive to see just how many students are involved in online education at the present time, as well as to see the actual annual growth in online enrollments. This section provides a broad overview of online learning - a "view from 35,000 feet”, so to speak.

\section{A. Entering the Mainstream}

In the fall of 2004, Sloan-C published its second survey of online learning, entitled "Entering the Mainstream: The Quality and Extent of Online Education in the United States, 2003 and 2004.” [2] This survey was focused on several fundamental questions regarding the nature and extent of online education. One key question involved the number of enrollments in online classes, and another key question involved the rate at which these enrollments were growing. The survey found that 1.9 million students were studying online in the fall of 2003, and that this number was expected to grow to over 2.6 million by the fall of 2004. The average annual rate of growth of online enrollments was expected to exceed $20 \%$.

The survey also examined online enrollments by sector, as shown in the following diagram:

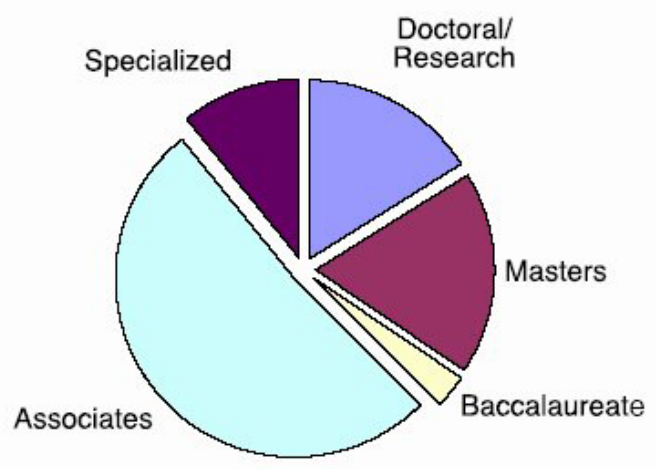

Figure 1: Online Enrollments by Type of Institution (Highest Degree Granted), From [2].

It is striking to note that more than one-half of all the online enrollments were from community colleges (the institutions that grant Associate's degrees). However, given that community colleges have nearly half of the total enrollments in higher education in the nation [6], the large contribution of these institutions to online enrollment may not be surprising. Equally striking is that the lowest enrollments by sector came from baccalaureate degree granting institutions (presumably small, residential, 4-year liberal arts colleges).

Another key question addressed by the second Sloan-C survey related to the role that online learning has in the long-term strategy of the institution. The survey found that the majority of all schools (53.6\%) stated that online education is critical to their long-term strategy. Among public and private for-profit institutions, almost two-thirds (over 65\% in both cases) reported that that online learning is important in the long-term. The larger the institution, the more likely it believes that online education is critical. Baccalaureate degree-granting institutions, which have the lowest online enrollments, did not report that online learning was of strategic importance. 
Another important piece of data drawn from the most recent Sloan-C survey can be seen in Figure 2 below, which shows that public institutions generate over $80 \%$ of online enrollments, compared to $20 \%$ from the private non-profits and for-profits combined. It is likely that public colleges and universities will continue to provide the largest percentage of online enrollments in the foreseeable future, and also will likely provide the largest growth in terms of absolute numbers of online students. However, the private for-profit institutions appear to have the largest percentage growth rates (see Section V, below), so it is not inconceivable that these institutions will increase their market share in the coming decade.

Number of Online Students Fall 2003

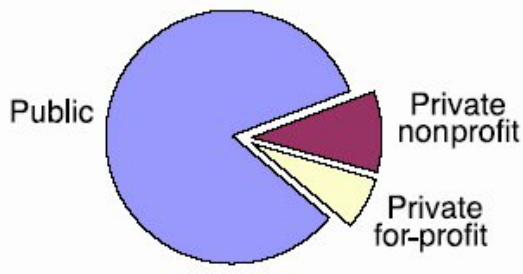

Figure 2: Online Enrollments by Type of Institution (Public, Private Non-profit, Private for-profit), From [2].

\section{B. Other Evidence of Strong Growth of Online Enrollments}

\section{SUNY Learning Network}

The State University of New York (SUNY) implemented the SUNY Learning Network (SLN) in 1995, beginning with eight online classes. The SLN is now a national leader in providing access to quality online education, and it has grown to provide a total of 85 online certificate and degree programs; 40 of the 64 SUNY campuses are participating in the SLN. In the 2004-2005 academic year, there were over 106,000 total enrollments in 4,862 online courses. SLN has experienced a $100 \%$ enrollment growth since the 2002-2003 academic year [7].

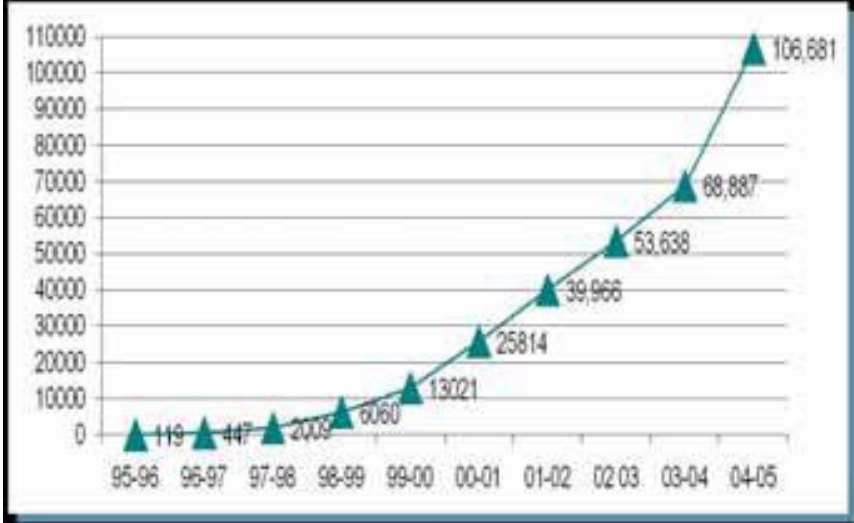

Figure 3: Growth of Annual Online Enrollments in the SUNY Learning Network, From [7].

\section{Illinois Virtual Campus}

The Illinois Virtual Campus (IVC) consists of 71 public and private colleges and universities in Illinois that offer online courses and degrees. Each semester, the IVC collects enrollment data from its participating institutions. During the Fall 2004 term, Illinois colleges and universities reported 80,165 
enrollments in 5,279 online courses. This was an increase of 30,072 enrollments (60\%) from the 50,093 enrollments reported for the Fall 2003 term. The online enrollment during the Fall term for the past six years is shown in the following figure:

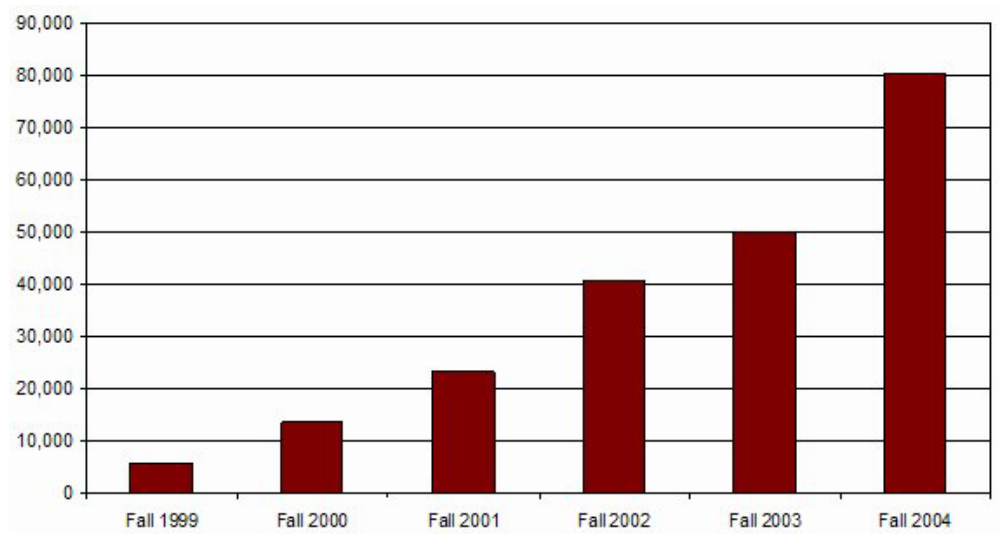

Figure 4: Online Enrollment for the Fall Term Reported by the IVC, From [8].

The data from the IVC are somewhat distorted by one major for-profit institution headquartered in Illinois (DeVry), which has a national presence; the online enrollments reported by DeVry increased by 203\% between 2003 and 2004. However, even if the DeVry enrollments were excluded from the IVC totals, the Fall 2004 numbers would show an enrollment increase of 29.3\% (from 41,229 to 53,314) [8].

Overall, it is clear that online enrollments nationally have experienced very large growth during the past decade, and evidence points that this growth will continue in the next few years. The aggregate enrollment data presented above, however, do not provide any information as to what is responsible for driving this growth. In the next section, therefore, institutions that have scaled will be examined in greater detail.

\section{SUCCESSFUL IMPLEMENTATIONS THAT HAVE ACHIEVED SIGNIFICANT SCALE}

In examining how institutions can scale-up their online programs to meet increasing demand, it is instructive to analyze a number of institutions that have achieved significant scale in their online programs. Through this analysis, a number of common factors emerge that have contributed to the success of these institutions.

\section{A. Herkimer County Community College}

Herkimer County Community College (HCCC) is part of the SUNY Learning Network. HCCC offered its first online courses in the fall 1997 term - three courses that enrolled a total of 36 students. By the 200304 academic year, the online initiative at HCCC had grown so that fully $28 \%$ of all enrollments at HCCC were in online courses. HCCC currently offers 18 two-year associate's degrees and 3 one-year certificate programs entirely online. At the Spring 2005 graduation, 86 of the 519 graduates had earned their degrees completely online.

A number of factors have contributed to the success of the online program at HCCC, including (1) emphasis on programs, not just courses, (2) high quality courses - the online courses are taught by the 
same professors who teach on the campus, (3) comparable student services for online and on-campus students, (4) individualized attention to the needs (and complaints) of online students, and (5) highquality faculty training and support.

HCCC has been able to achieve significant scale in its online program, due in part to strong administrative support, strong faculty buy-in to online teaching ( $75 \%$ of the eligible faculty at HCCC teach online), and the support from the SUNY Learning Network in providing the technology infrastructure, helpdesk, faculty training, and marketing [9].

\section{B. University of Illinois at Springfield}

The University of Illinois at Springfield (UIS) started its online program in 1998 with two online courses. It now offers ten online degrees and more than 300 different online courses. During the Spring 2005 semester, $34.5 \%$ of the students (more than 1 in 3) took at least one online course, $18 \%$ of the students (more than 1 in 6 ) took online courses exclusively, and $22 \%$ of all course credits were generated by online courses. In the summer of 2005, UIS reached the milestone of exceeding 20,000 online enrollments, and $48 \%$ of all the course credits in the summer semester were generated by online classes [8]. While UIS traditionally has served students from central Illinois, the online program has more than $20 \%$ of its students from out-of-state, with California being the top provider of out-of-state students. UIS is able to attract out-of-state students due to its e-tuition policy: residents of Illinois automatically qualify for etuition (which is currently equal to in-state tuition), while out-of-state students qualify for e-tuition during a particular semester if they are enrolled in an online degree program and only take online classes that semester [10].

As an example of scaling enrollments, the online Master in Teacher Leadership (MTL) degree at UIS was started in the Fall 2000 semester and has served over 490 students since that time. Students have enrolled in the program from twenty-two states and seven other countries. There are now 107 graduates of the program. The MTL program currently has over 360 enrolled students, with more than 100 added this past year alone. MTL is a unique curriculum that appeals to a "teacher leader" -an in-service teacher who wants an advanced degree that emphasizes leadership, but who does not want to become a principal [11].

The UIS campus has been able to scale its online program for several reasons. The campus has a history of using technology to serve non-traditional students, and many of the faculty view online as just the latest step in this process. The campus created an "Office of Technology-Enhanced Learning" (OTEL) to support its online faculty; this strong support made a difference to faculty who were just starting to teach online. E-tuition certainly has allowed the campus to garner national and even international enrollments. A technology fee assessed to online students (\$25 per credit hour) provides additional funds to support the online initiative [10].

In developing its online program, UIS overcame several obstacles, including administrative and faculty resistance. Certain administrators were concerned that the online program was "cannibalizing" on-campus enrollments; but data from Banner [the university-wide ERP] showed that online is bringing in significant new enrollments. Faculty who did not understand online were not willing to accept a vision of teaching and learning outside of a physical classroom; while much of this resistance has been overcome, some departments remain unwilling to put their degrees online [10]. 


\section{UMass Lowell}

UMass Lowell, one of the five campuses in the UMass system, launched its online program in 1996 as part of a strategic initiative to generate surplus revenues for the campus. The program started in its Division of Continuing Studies and Corporate Education (CSCE) with a handful of pioneering faculty and a home-grown learning management system. During its first three years, UMass Lowell online enrollments grew at staggering rates of $50-100 \%$ per year. This year, online enrollments and reached 7,500 and generated nearly $\$ 8,000,000$ in gross revenue.

UMass Lowell offers ten online degrees from the associate's to the doctoral level, as well as thirteen online certificates, and is now part of the UMassOnline (UMOL), the system portal to online education. In addition to generating large revenue surpluses for the campus (the program has exceeded its financial margins for three consecutive years), the online program is credited with increasing degree completion in continuing education by $25 \%$ each year for the past three years, something critical to the workforce development needs of the region.

A cornerstone of the Lowell model is careful attention to strategic planning done in tandem with academic departments [12]. Beginning with a mandate from the Chancellor and a plan for providing incentives to Deans, Department Chairs and faculty, the academic leadership of the campus worked in incremental stages to develop the broad array of offerings currently available.

Investments in technology infrastructure were augmented by deep investments in program and faculty development. A team of program development professionals, marketing staff and online course developers work with deans and department chairs to manage the development of programs from inception. As a result, out of the 23 programs launched to date, 22 have been very successful in bringing new students to the campus, generating revenue, and bringing national recognition to the campus.

In each case, the online education program was developed to address a problem identified by the department. For example, the Graduate School of Education's Master's in Educational Administration had only eleven matriculated students when the faculty reluctantly opted to move their degree online. Within one year, the number of matriculated students had tripled and has climbed to over 125 matriculated students. This year, there were twenty-four online graduates in the Education program. On the opposite side of the equation, the Criminal Justice Department had more demand than the department could handle. Working with CE and UMOL, the department accommodates the excess capacity through an online Master's Degree. The Criminal Justice Degree alone generated nearly $\$ 750,000$ last year in gross revenue, doubled the number of matriculated students, and provided funding for faculty, teaching assistants and clerical support for the Department. Again, programs designed to solve problems at the departmental level result in high engagement of the faculty, administration and ultimately have the greatest chances of success.

The online program at UMass Lowell is supported by UMassOnline, which provides a main portal to its online programs, a learning management system, and marketing and program development assistance. UMassOnline was funded specifically to generate revenues to offset declining budgets from the state. Members of the continuing education and outreach programs on the five UMass campuses help to guide policy decisions and to identify program development initiatives. UMassOnline revenues and enrollments have grown steadily on average at 50\% per year. Enrollments across the system are now over 17,000 and the total revenue generated exceeded $\$ 17,000,000$. 


\section{Upper Iowa University}

Upper Iowa University (UIU) is a non-profit, non-denominational private institution in northeast Iowa, which enrolls 5500 students on several campuses and through several distance learning initiatives. UIU started its online program in the fall of 1999 with 36 enrollments. It now has scaled to the point of having 1000 students currently taking online courses; these students come from 38 states and 6 foreign countries.

UIU has a very different model for online education, in that the faculty teaching online are completely separate from the faculty on the main campus. They are all adjunct faculty, and $20 \%$ are tenured at other institutions. The seventy UIU online faculty span the nation-from Hawaii to New York, from the Canadian to the Mexican borders. Eighty-five percent of the online faculty have terminal degrees in their fields. Full-time faculty on the residential campus provide broad oversight of online courses, as well as control over hiring online faculty.

The online program at UIU is fully self-supporting; in fact, it returns a surplus to the campus. The success of this program is related to several things, including the quality of the faculty, excellent student support (with a strong focus on customer service), and a national marketing campaign. Since it is a small institution, UIU has developed its online program on a "shoestring". It has kept fixed costs low, and outsourced certain functions when it made sense (such as IT support and the help desk). The online program is designed to serve students in the rural upper Midwest, and therefore assumes that students will be connecting via a $28.8 \mathrm{kbps}$ modem. UIU has the same tuition for out-of-state students, and a $10 \%$ military discount. As with so many other successful implementations, the online program at UIU has strong administrative support from the institution’s President and Board of Trustees.

At this point, the main obstacle to continued scaling of online enrollments at UIU is identifying qualified faculty, and hiring and training them [13].

\section{E. Stevens Institute of Technology}

Stevens Institute of Technology is unique among institutions with successful online programs, in that it emphasizes engineering and technology. Stevens currently has scaled its online program to 12 master's degrees and 35 certificate programs, consisting of 200 individual courses. Since the start of the online initiative 5 years ago, Stevens has had 7000 cumulative online enrollments; and is on a path to reach 10,000 cumulative online enrollments by spring 2006. During FY05, the online program had 2,660 course enrollments and generated $\$ 4.5$ million revenue. Because of its focus on engineering and technology at the post-baccalaureate level, $85 \%$ of its online students get tuition reimbursement from their companies; companies are now putting caps on tuition reimbursement, and this could limit future growth. Stevens has an aggressive initiative in affinity marketing, working with 10 professional societies (ASME, IEEE, etc.) who market its online programs. In return, Stevens gives tuition discount to society members. In addition, Stevens has a close relationship with 20-30 companies, where its online programs are listed on the companies' internal intranets under educational resources and providers. Stevens has concentrated on developing online versions of its on-campus degrees and certificate programs that are in the highest demand.

The online program at Stevens has had great institutional support-especially since the online program provides revenue to the campus, and extends the Stevens brand nationally and worldwide. As with so many other non-profit institutions, the impediments to future growth are faculty resistance to online and to hiring adjuncts [14]. 


\section{F. Washington State University}

Washington State University (WSU) enrolls more than 22,000 undergraduate and graduate students on its primary campuses. It has a highly successful online program, with approximately 15,000 course enrollments each year. It currently has 6 undergraduate and 2 graduate degrees, 3 certificates, and 200 courses available online. WSU has developed a funding model that motivates faculty and departments to scale online enrollments (additional revenues are provided to departments for each online student, and faculty are compensated on a per-student basis).

WSU has addressed a number of important issues as it has scaled-up its online program:

- Changes in faculty perceptions about teaching. The course design/development process at WSU helps faculty move to a focus on student learning, rather than on faculty teaching.

- Scaling support services. As the number of courses and number of enrollments have grown, WSU has had to scale-up its support services to accommodate this growth. They have moved as much of their support services as possible to the web so that students can serve themselves, rather than relying on contacting WSU staff-greatly reducing the number of phone calls handled. Continued work in this area is essential for continued growth.

- Focus on programs, not individual courses. Most of their undergraduate degree programs are inter-related, so students can use courses in one area as part of a program in another area. This has reduced the total number of courses needed to offer multiple programs.

- Focus first on the willing. Initial online projects involved faculty, departments, and colleges that were willing partners, rather than trying to work with skeptical units. Based on their initial success, it became much easier to motivate others to get involved [15].

\section{G. Capella University}

Capella University is a for-profit institution that has developed a significant online program, which targets adult students. Capella offers online degree and certificate programs in business and technology, education, human services, psychology, and undergraduate studies. As of March 2005, it had a student headcount of 12,900 and an FTE enrollment of 5,500. It has scaled its online enrollments through the use of part-time and adjunct faculty, with $85 \%$ of its faculty belonging to this category. Capella faculty live in all 50 states and in six foreign countries, and are required to participate in a rigorous professional development program to prepare them to teach online. Partnerships are a notable feature to increasing enrollments at Capella; it has corporate alliances with 85 companies-including Boeing and Xerox-as well as alliances with more than $25 \%$ of community colleges in the United States. Capella also offers a 10-15\% tuition discount to members of the U.S. Armed Forces. Much of the success of Capella University can be attributed to its emphasis on providing student support services online, including academic advisors, career counselors, financial aid, tech support, online librarians and library resources, an online writing center, and online access to the registrar, the bookstore, and its alumni center [16].

\section{CHARACTERISTICS OF SUCCESSFUL IMPLEMENTATIONS}

In reviewing the successful online initiatives described in the previous section, a number of common themes are seen to be present, as detailed below.

1. Strong institutional support characterized by integration of the online programs in the campus mission and strategic plan. Successful online programs have been developed where there is a clear institutional mission to serve off-campus, distance, and non-traditional students. This institutional support is apparent at all levels, from department heads to deans to provosts to presidents to trustees. 
2. Specialized units dedicated the development and support of online programs. These units include system organizations that enable multiple campuses to grow programs and Continuing Education units that have the flexibility to assess market interest, develop high-demand programs, set tuition rates, and hire increasing numbers of adjunct faculty when needed. Typically, these dedicated units support robust technology infrastructures, including outsourcing when necessary.

3. Financial models that encourage scaling of online programs either through reinvesting of net revenue in campus units and/or through self-supported initiatives. Institutions that have scaled successfully have developed various incentives to faculty, departments and deans to expand enrollments. For public, state-funded colleges and universities, the capacity to move beyond outof-state tuition to a market-driven tuition rate is critical.

4. Program development emphasizes the delivery of complete online degrees, rather than individual online courses. Successful institutions have a disciplined approach to program development, due to the upfront costs of course development, marketing of programs, and hosting expenses. These institutions also have taken a methodical approach to program development based on market demand, and a willingness and capacity of their departments to deliver these programs.

5. Pedagogy and course design that emphasizes interaction among students and faculty. Many prospective students, as well as faculty, remain concerned that online courses will have less interaction than they experience in their face-to-face courses. This remains a major obstacle to scaling online programs despite all the research that shows otherwise. The successful programs described above all emphasize faculty-led instruction that facilitates interaction and the creation of community within the courses.

6. Marketing initiatives insure that online programs reach their target enrollments. Such initiatives are an essential and often overlooked aspect of scaling online programs, and marketing is given minimal support at many institutions. The institutions described above have invested significant financial and human resources in marketing their online programs.

7. High quality training and support for online faculty. Faculty professional development programs are critical to overcoming faculty skepticism and resistance to online education. Successful online initiatives have required faculty to participate in extensive training programs and created related professional development opportunities for the faculty. At many institutions, the best online faculty have been recruited to assist with the development of new online faculty, thereby building a community of engaged faculty working to improve the quality of their online courses.

8. Student support services that meet the needs of online students, with students treated as customers. Such support includes the registrar, business office, financial aid, and program advising - a one-stop shop for students. The for-profit institutions typically excel in this crucial area.

9. The ability of the institution to scale its online faculty. Perhaps the most important characteristic of the institutions that have scaled their online enrollments is their ability to increase the number of online course sections offered by successfully recruiting and training qualified adjunct faculty. Without an ever-increasing pool of faculty, online enrollments will remain stagnant.

10. An emphasis on teaching and/or outreach and continuing education. Institutions that have scaled successfully often have a history of serving off-campus students. Large research universities have competing agendas and often are unable to commit the necessary academic resources to scale their online programs (more below).

\section{ANALYSIS OF INSTITUTIONS ACHIEVING VERY LARGE SCALE}

A number of online institutions now have well over 10,000 students each, including the University of Phoenix, DeVry University, Strayer University, Career Education Corporation, Capella University, 
Kaplan University, and Laureate International Universities. These institutions are characterized by their marketing and promotion, spending hundreds of millions of dollars on lead generation and branding. Such extensive marketing, combined with open admissions policies, has vaulted these degree-granting, forprofit institutions to a dramatic level of scale. Eduventures estimates that there were well over 300,000 unique students enrolled in 100\% online programs at for-profit institutions at the end of 2004, and it expects this enrollment figure to grow nearly $40 \%$ by the end of 2005 . Based on benchmarking surveys conducted by Eduventures, this means that for-profits will spend nearly $\$ 1.5$ billion (about $20 \%$ of their revenue) on marketing online programs in 2005, and this could be a conservative estimate [17].

A number of institutions with very large online enrollments share other characteristics: outsourcing to third-party providers or participation in some type of consortium. To some extent this goes hand-in-hand with marketing, but many of the apparently largest institutions are participating in eArmyU (e.g., Troy State University, St. Leo University, Embry-Riddle Aeronautical University, Thomas Edison State College, St. Joseph's College of Maine); members of the "University Alliance" operated by Bisk Education (e.g., Regis University, St. Leo University); relationships with service providers like eCollege (Strayer University, DeVry University, University of Wyoming, Montana State University) or Compass Knowledge Group (University of Cincinnati, University of Florida).

The online education market may be bifurcating into at least two-tiers [17]. One tier is a "national" market in which it is increasingly expensive to build awareness and to compete. The other tier is a regional market. Much of the online enrollment growth will come locally as students in Illinois, for example, who think "University of Illinois" when they think higher education, simply choose to enroll at a familiar institution - they will not have to look nationally to relatively unknown institutions because the institutions that they are familiar with and "in their back yard" will hopefully be offering what they need. Given equal levels of awareness, it is likely that many more prospective students would be familiar with the University of Illinois at Springfield or UMass Lowell and would consider enrolling than would know the ECPI College of Technology or Westwood College. However, there will still be the University of Phoenix and other nationally known institutions that will develop national brands through marketing investments and solid outcomes and then will reap those benefits.

\section{OBSTACLES TO SCALING AT NON-PROFIT INSTITUTIONS}

A number of institutions in higher education have not scaled their online programs. Why have they not enrolled more students? What is preventing them from growing?

A number of general impediments to scaling online programs come to mind: a lack of institutional mission to serve off-campus students, faculty focus on research, cost of online program development and lack of access to investment capital, limitations of technology infrastructure, cuts in state funding of public institutions, faculty resistance to change, faculty resistance to use of adjunct faculty, etc.

Just as it was worthwhile to examine a number of institutions that have scaled successfully, it also is instructive to examine an institution that has not scaled. The University of Illinois at Urbana-Champaign (UIUC) is a Research I university. The campus was an early leader in the use of computers and the Internet in its academic programs, and its online master's degree in Library and Information Science was the recipient of the inaugural (2001) Sloan-C award for the most outstanding online program [18]. However, other than a few limited online degrees at the graduate level, UIUC has not developed a significant number of online degree programs, either in breadth or scale. There are a number of reasons that have prevented this campus from having a significant online presence: 
1. UIUC is a research-intensive university - while innovation in instruction is valued, spending time on research has a higher priority for most faculty. There is no history of employing "teaching faculty" or adjunct faculty.

2. At the undergraduate level, UIUC has very selective admissions criteria, and it cannot accommodate all the demand from graduating high school students in the state. Undergraduate instruction is done in residence, and the campus has stringent residency requirements. The campus has emphasized expanding its capacity for residential instruction (enrolling a record number of incoming freshman in the fall of 2004), rather than trying to reach undergraduate students at a distance.

3. The unit that supports educational technologies on the campus sees its mission as supporting oncampus instruction.

4. Academic Outreach (the extension unit on the campus) is committed to helping students offcampus, but also marginalizes those efforts from the mainstream of most college activity, where program development responsibility rests. In addition, Academic Outreach does not offer any complete degrees.

5. Online programs can thrive where the authority to commit resources is available-as in the Graduate School of Library and Information Sciences. For programs at the department level within a college, they must compete with other college initiatives for resources.

In addition to institutions that have limited niche online programs, there are a number of institutions of higher education that do not offer any online courses or degrees at all, such as Illinois Wesleyan University and Knox College. These small, private, non-profit institutions emphasize residential instruction, and to date, do not see off-campus instruction as consistent with their mission. Based on the recent Sloan-C survey [2], these small, baccalaureate-degree-granting institutions do not see online learning as critical to their future.

There also are institutional (mis)perceptions that must be overcome if online education is to move into the mainstream. An example recently appeared in the student newspaper at the University of California at Berkeley:

"If a student is interested in taking an online course, it needs to be approved by an advisor in advance," said Ken Mahru, a UC Berkeley undergraduate English advisor. "But I think it's important to take courses here on campus." Only one online course will be accepted for the English major, although without a definite policy, each request is reviewed on a case by case basis, Mahru said. While the English department has not seen a rise in students using online courses, the repercussions of taking an online course outweigh the immediate benefits, Mahru said. "Graduate schools will not be fooled by online courses," he said. [19]

\section{FUTURE OPPORTUNITIES FOR ONLINE ENROLLMENT GROWTH}

\section{A. Growth in the Demand for Online Learning}

Online learning clearly is still in a growth mode [2]. There is increasing demand from various segments of the population, as detailed elsewhere in this monograph [20, 21]. Growth areas include traditional oncampus students, non-traditional adult students, employees of corporations, and retirees. But the largest demand may lie ahead, as the "digital natives" enter higher education. The Internet now plays an important role in $\mathrm{K}-12$ education, and an increasing number of high school students are taking courses online [22]. Indeed, preschool children are now starting to use the Internet: 
Before they can even read, nearly one out of every four children in preschool is learning a skill that even some adults have yet to master: using the Internet. Some $23 \%$ of children in nursery school-kids ages 3, 4, or 5-have gone online, according to an Education Department (ED) report. By kindergarten, 32\% have used the internet, typically under adult supervision. The numbers underscore a trend in which the largest group of new users of the Internet are kids ages 2 to 5. These figures have important implications for school systems, which must adjust their methods of instruction to accommodate an increasingly tech-savvy generation of new students, experts say. [23]

Based on this type of anecdotal evidence, as well as recent survey data [2], the demand for online higher education should continue to increase in the coming years. But will colleges and universities scale-up their online programs to meet this demand?

\section{B. Scaling Online Learning}

In the public university sector, why does Northeastern Illinois University (NEIU), an institution with 12,164 headcount enrollments on the campus during the Fall 2004 semester, have zero online enrollments, while UIS, with about one-third the number of students as NEIU, have over 2,000 online course enrollments in one semester [8, 24]? Both are largely commuter institutions. Both serve nontraditional students. Similarly, why does Southern Illinois University at Edwardsville (SIU-E) have only 194 online enrollments in one semester, but more than four-times the FTE enrollment as UIS [8, 24]? In the community college sector, why have some community colleges embraced online (Parkland College, HCCC), while others have only a very limited online presence (Kankakee Community College, Highland Community College) [8, 9, 24].

One might ask why some institutions have not embraced online learning. Have they consciously ceded online learning to other institutions? Or are they being left behind because they are unaware of the potential of online learning? Is there something that Sloan-C should be doing to assist these lagging institutions develop robust online programs? Are more programs like the Sloan Greater NYC Online Learning Center [25] needed to encourage all types of institutions to develop online initiatives?

Will the non-profit institutions respond to the marketplace? Will they embrace online learning as a way of reaching new markets, or better serving their current students? Or will the largest growth continue to be in the for-profit sector (and those institutions that behave like for-profits, such as UMUC)?

Successful models for large-scale implementations of online learning exist. These models use a wide range of approaches, and have lead to a growing body of practical knowledge of what is needed to insure success. The unanswered question is whether the non-profit sector will realize that online learning is a disruptive agent [26], and change accordingly, or if only a limited number of institutions will achieve significant scale. The positive aspect of this situation is that online learning is still a very new field, and it is not too late for institutions to start online programs. Of course, every year that institutions wait gives their "competitors" additional market share.

Overall, to continue to increase the supply of online learning to meet an ever-increasing demand for this form of education, there must be:

- A broader base of institutions providing online programs, including all segments of higher education (ranging from HBCU's to tribal colleges to R1 institutions); 
- An increased breadth of online course and program offerings; for example, the SUNY Learning Network just announced that it will be offering a BS degree in electrical engineering [7];

- A major effort to scale existing online programs, using the common approaches outlined in this chapter.

\section{RECOMMENDATIONS FOR ACTION}

The Alfred P. Sloan Foundation has had remarkable success in catalyzing the expansion of ALN programs since it started its "Learning Outside the Classroom" initiative in 1992. It has achieved this success through two parallel efforts - direct grants to institutions, which have enabled them to increase the scale and breadth of their online programs, and creation of the Sloan Consortium (Sloan-C), which serves to disseminate knowledge about ALN through publications, workshops, conferences, and its website. Taken as a whole, these activities have addressed each of the five pillars, with the clear goal of increasing access to higher education. There is still much to be gained by continuing these activities, and the authors would like to make the following specific recommendations to the higher education community, including academic leaders, the Alfred P. Sloan Foundation and other foundations, and to Sloan-C members in light of the analysis presented in this paper.

1. Program Development: The Alfred P. Sloan Foundation's grant program has played a critical role in the expansion of degree programs, and it and other organizations should continue this effort in targeted areas. For example, the recent funding of an online baccalaureate degree program in electrical engineering will show that it is possible to deliver high-quality degrees online in engineering and science. Other funding opportunities would be to expand the range of institutions involved in providing ALN degrees, including HBCU's and tribal colleges.

2. Faculty Recruitment, Pedagogy and Course Development: Sloan-C can also move in new directions to increase access to online education. One of the main challenges facing institutions today is expanding their capacity by hiring new online faculty; Sloan-C could provide an online faculty registry, where qualified faculty could post their résumés for interested institutions to view. Sloan- $C$ could also partner with various training organizations to provide professional development for faculty who are interested in teaching online.

3. Access and Student Orientation: Of course, Sloan-C could take on an expanded role in promoting online education to potential students; this would be done through an expanded online catalog of ALN courses and programs, enhanced with important "consumer" information that would be of interest to those individuals who are new to online education. Outreach and orientation to students from an organization such as Sloan-C could assist the public by continuing to debunk some of the myths that still inhibit student participation in online education.

4. Financial and Business Models: One of the major findings of the successful programs outlined above was the disciplined approach each took to developing business models for developing and sustaining the programs. Sloan-C has provided some important seminars and studies in this area, but needs to continue to expand its repertoire of models as new opportunities evolve. For example, all three of the public higher education systems presented in this paper have taken different approaches to funding their online programs, yet each has yielded impressive results. Similarly, marketing has emerged as a critical component of successful online programs, yet many institutions are neglecting this important activity. The Alfred P. Sloan Foundation should consider expanding funding to include inter- institutional studies of best practices for financial and business models. 
5. Institutional Support and Leadership: The Alfred P. Sloan Foundation should reach out to the presidents and chancellors of colleges and universities throughout the country-those individuals who are in a position to enunciate the vision and define the mission for their institutions-with an informational campaign about ALN and its potential impact. It is critical that these senior leaders be made aware of all aspects of ALN, and how the new online approaches to education really constitute a "hugely disruptive force” [27] that is changing the landscape of higher education as we know it.

Undoubtedly, one of the major contributions that the Alfred P. Sloan Foundation and the Sloan Consortium have made is the creation of a learning community focused on online education that spans the entire nation. The broad participation and collaboration of higher education faculty and administrators in Sloan-C activities gives evidence that this leadership must be sustained and expanded if the continued growth of online education is to be realized.

\section{CONCLUSIONS}

There is much evidence to support the emerging consensus that online education will continue to be one of the fastest growing markets in American higher education for the foreseeable future; student demand for online courses and programs still continues to exceed the supply. While a number of obstacles to scaling online programs remain at many traditional bricks-and-mortar institutions, institutions across the country are overcoming these obstacles by creating new organizational structures that facilitate the growth of online education. Overall, this chapter has provided an analysis of many of the key characteristics of a select set of institutions that have achieved significant scale in their online programs, and has provided some direction for what other institutions should do to expand their own online offerings.

\section{ACKNOWLEDGMENTS}

The authors thank John Bourne and Ray Schroeder for their insightful comments on an earlier draft of this manuscript. They also are indebted to numerous individuals who shared details of their online initiatives that are described herein. Finally, the authors thank Dr. A. Frank Mayadas and the Alfred P. Sloan Foundation for over a decade of strong support for online initiatives throughout the nation.

\section{REFERENCES}

1. Miller, G. E. An Interview with Frank Mayadas of the Alfred P. Sloan Foundation. The American Journal of Distance Education 11(3): 1997.

2. Allen, I. E. and J. Seaman. Entering the Mainstream: The Quality and Extent of Online Education in the United States, 2003 and 2004. Needham, MA: Sloan-C, 2004. http://www.sloan-c.org /resources/survey04a.asp.

3. The Sloan Consortium Website. About Sloan-C. http://www.sloan-c.org/aboutus/.

4. Bourne, J. R. and J. C. Moore (eds.). Elements of Quality Online Education: Into the Mainstream, Volume 5 in the Sloan-C Series. Needham, MA: Sloan-C, 2003.

5. Mayadas, A. F. Quality Framework for Online Education, In B. Panitz, Learning on Demand, ASEE Prism. Washington, D.C.: American Society for Engineering Education, 1998.

6. Kasper, H. The changing role of community college. Occupational Outlook Quarterly 43(4): 14-21, Winter 2003-2003. http://www.bls.gov/opub/ooq/2002/winter/art02.pdf.

7. Porush, D. State University of New York. Personal communication. June 2005.

8. Illinois Virtual Campus. Distance Education Enrollments, Illinois Colleges and Universities, Fall 2004. http://www.ivc.illinois.edu/pubs/enrollment/Fall_04.html. 
9. Pelz, W. Herkimer County Community College. Personal communication. June 2005.

10. Schroeder, R. University of Illinois at Springfield. Personal communication. June 2005.

11. Stonecipher, L. University of Illinois at Springfield. Personal communication. June 2005.

12. Moloney, J. and S. Tello. Principles for Building Success in Online Education. Syllabus 16(7): 2003.

13. Binder, D. Upper Iowa University. Personal communication. June 2005.

14. Ubell, R. Stevens Institute of Technology. Personal communication. June 2005.

15. Oaks, M. Washington State University. Personal communication. June 2005.

16. Pearce, K. Capella University. Personal communication. June 2005.

17. Gallagher, S. Eduventures. Personal communication. May 2005.

18. The Sloan Consortium Website. Awards. http://www.sloan-c.org/aboutus/awards.asp.

19. Louie, V. Double-Clicking Through College. The Daily Californian: July 5, 2005. http://www .dailycal.org/sharticle.php?id=18952.

20. Booth, W. Insuring the nations' destiny: Reducing the digital divide. Journal of Asynchronous Learning Networks 10(3): July 2006 (this issue). http://www.sloan-c.org/publications/jaln/v10n3 /v10n3 5booth member.asp (login required).

21. Ettinger, L. Reaching asynchronous learners within the Silver Tsunami. Journal of Asynchronous Learning Networks 10(3): July 2006 (this issue). http://www.sloan-c.org/publications/jaln/ v10n3/v10n3_4ettinger_member.asp (login required).

22. Thompson, M. Online K-12 education: Opportunities for collaboration with higher education. Journal of Asynchronous Learning Networks 10(3): July 2006 (this issue). http://www.sloan-c.org /publications/jaln/v10n3/v10n3_3thompson_member.asp (login required).

23. eSchool News Online. More preschoolers going online. 7 June 2005. http://www.eschoolnews.com /news/showStoryts.cfm?ArticleID=5723.

24. Illinois Board of Higher Education. Preliminary Fall 2004 Enrollments in Illinois Higher Education, Dec. 2004, http://www.ibhe.org/Board/Agendas/2004/December/Item\%20II-3.pdf.

25. Cacciarelli, E. Sloan Center boosts ALN at NYC regional schools. Sloan-C View 3(8): September 2004. http://www.sloan-c.org/publications/view/v3n8/coverv3n8.htm.

26. SchWeber, C. A Tipping Point for Online Education? Sloan-C View 4(3): March 2005.

27. Friedman, T. L. The World Is Flat: A Brief History of the Twenty-first Century. New York: Farrar, Straus and Giroux, 2005.

\section{ABOUT THE AUTHORS}

Dr. Jacqueline Moloney is Executive in Residence for UMassOnline and the Dean of the Division of Continuing Studies, Corporate and Distance Education at UMass Lowell. Under Dr. Moloney's leadership, UMass Lowell became an early pioneer in online education and is a major contributor to UMassOnline, the system's online education program. Known for her commitment to faculty development and curriculum innovation, Dr. Moloney has led the development of numerous faculty and program development initiatives and established the Faculty Teaching Center and the Centers for Learning at UMass Lowell. As Dean she redesigned UML's traditional evening program into one of New England's premier professional education programs that features cutting edge curricula on-campus, onsite at companies and online. As a member of the Board of Directors for the Sloan Consortium of Asynchronous Learning Networks, Dr. Moloney is the Sloan-C International Conference Chair and is an active contributor to the national dialogue on the development of online education. She has served with numerous professional organizations and authored articles on the development and assessment of online programs, the use of technologies in the classroom; cross-disciplinary approaches to curriculum reform; and the organizational reform of higher education. She is a champion of community involvement and is active on numerous civic boards. Contact info: see http://www.continuinged.uml.edu/jmoloney. 
Burks Oakley II is the Associate Vice President for Academic Affairs at the University of Illinois and serves as the director of University of Illinois Online. Through his innovative use of technology in teaching, Oakley has earned a national reputation as a practitioner and promoter of online education. In the past five years, he has given more than three hundred invited talks at national conferences and on university campuses. Oakley received his B.S. degree from Northwestern University and his M.S. and Ph.D. degrees from the University of Michigan. He has received numerous awards for his teaching and innovative use of technology in education, including the Luckman Distinguished Undergraduate Teaching Award from UIUC in 1993, the Outstanding Teacher Award from the American Society for Engineering Education (ASEE) in 1993, the Educom Medal in 1996, the Major Educational Innovation Award from the Institute of Electrical and Electronics Engineers (IEEE) in 1996, the IEEE Third Millennium Medal in 2000, the Achievement Award from the IEEE Education Society in 2002, the Engineering Alumni Society Merit Award from the University of Michigan in 2003, and the Sloan-C Award for the "Most Outstanding Achievement in Online Teaching and Learning by an Individual" in 2003. He is a Fellow of the IEEE and the ASEE, a former Vice President of ASEE, and a member of the Board of Directors of the Sloan Consortium. Contact: Burks Oakley II, 337 Henry Administration Building, University of Illinois, 506 S. Wright Street, Urbana, IL 61801. Telephone: 217-244-6465; Fax: 217-333-5040; email: oakley@uillinois.edu. 